\title{
PENDIDIKAN REMAJA DALAM KELUARGA DI DESA MERABUAN, KALIMANTAN BARAT (PERSPEKTIF PENDIDIKAN AGAMA ISLAM)
}

\author{
Aslan \\ Institut Agama Islam Sultan Muhammad Syafiuddin Sambas, Kalimatan Barat \\ aslanmarani@yahoo.com
}

\begin{abstract}
:
The research discusses adolescents as an issue of education in the family. As many experts recognize that family education is a major issue in the study of Islamic education. This is because the family is the first place for learning and planting Islamic values of a child to adolescence. In the context of family education, parents have a very vital position, in which parents become the main figures for a child in obtaining the internalization of the expected values in the family. This study is a field research that takes the site to families in Merabuan village, Sambas district, West Kalimantan, focusing on adolescents as the unit of analysis. Data collection techniques in this research using interviews, observation, and documentation. The findings of this research explain that family education conducted by families in Merabuan village through exemplary in the family environment, with the ways often provide guidance and advice, encouraging adolescents into youth members of the mosque, including adolescents praying in congregation in the mosque.
\end{abstract}

Keywords: Adolescents, Family education, Islamic education, Internalization of values.

\section{Pendahuluan}

Pendidikan Indonesia saat ini mengalami dilema yang luar biasa, baik yang dilakukan oleh anak-anak maupun sampai pada tingkat remaja. Di antara perbuatan yang dilakukan oleh anak/remaja adalah perbuatan yang tidak sesuai dengan nilai-nilai agama, seperti pacaran di usia dini yang mengakibatkan hamil di luar nikah, ${ }^{1}$ maupuan perbuatan menyimpang lainnya. Perilaku tersebut

\footnotetext{
${ }^{1}$ Widayati Lestari, "Peran Orang Tua Dalam Pendidikan Seks Pada Remaja" (Laporan Hasil Penelitian, Universitas Muhammadiyah Surakarta, 2015), hlm. 1-3. 
menggambarkan pendidikan dalam keluarga tidak semaksimal mungkin. Oleh karena itu, salah satu faktor yang paling menonjol dalam keberhasilan pendidikan adalah pendidikan dalam keluarga.

Keluarga adalah wadah yang pertama diterima oleh anak dalam pendidikan yang diajarkan oleh orang tuanya sendiri. Keluarga dalam memberikan pendidikan kepada anaknya yang dimulai masa anak-anak sampai remaja tidak terlepas dari pendidikan yang bernilai positif. Oleh karena itu, pada dasarnya pendidikan yang diberikan adalah perubahan untuk menciptakan generasi dari generasi selanjutnya kea rah yang lebih baik. ${ }^{2}$ Keluarga dapat diartikan sebagai pendidikan yang terkecil yang diterima oleh anak melalui sosialisasi. Orang tua dalam memberikan pendidikan kepada anaknya tidak terlepas dari tujuan yang ingin dicapai agar dapat menciptakan keluarga yang sakinah, mawadah dan warahmah. Keluarga diartikan juga sebagai penanaman pendidikan sosial, sehingga pendidikan dalam keluarga diartikan sebagai pengembangan dalam hal tingkah laku dan sikap perilaku anak. ${ }^{3}$ Dalam hal membina peranan anak dalam menciptakan keluarga yang tangguh bukan saja ditekankan kepada anak, tetapi tidak kalah pentingnya pada kedua orang tua, keluarga yang lain agar menciptakan hubungan yang harmonis. Selain itu, pola asuh dan pengajaran nilai-nilai agama yang diberikan oleh orang tua kepada anaknya mempengaruhi juga dalam kepribadian anak dan perilakunya. ${ }^{4}$

Orang tua dalam memberikan pendidikan kepada anaknya, bukan hanya pada masa anak-anak, tetapi sampai pada tingkat remaja. "remaja berasal dari bahasa Latin puberty atau pubertas dan adolescense yang artinya masa muda antara 17 dan 30". Masa remaja adalah masa peralihan anak-anak ke dewasa yang dimulai dari 12 tahun sampai masa 20 tahun. ${ }^{5}$ Oleh karena itu, orang tua sangat menentukan pembentukan perilaku anaknya menuju masa remaja atau masa dewasa.

\footnotetext{
${ }^{2}$ Wasty Soemanto, Pola Asub Orang Tua Dalam Membantu Anak. Mengembangkan Disiplin Diri (Jakarta: Rineka Cipta, 1998), hlm. 20.

${ }^{3}$ Syaiful Bahri, Psikologi Pendidikan (Jakarta: Akademika Presido, 1999), hlm. 1-10; Ahmadi, Sosiologi Pendidikan (Jakarta: Rineka Cipta, 2004), hlm. 167.

${ }^{4}$ Faturochman, "Peranan Keluarga, Sekolah Dan Masyarakat Dalam Pembentukan Kepribadian Remaja" (Laporan Hasil Penelitian Fakultas Psikologi, Universitas Gajah Mada, t.th.), hlm. 1-3; Bruce Chen, Sosiologi Sebagai Pengantar (Jakarta: Rineka Cipta, 1992), hlm. 172.

${ }^{5}$ Lestari, "Peran Orang Tua Dalam Pendidikan Seks Pada Remaja.", hlm. 17
} 
Di zaman era informasi saat ini, dengan berbagai kecanggihan teknologi, sehingga orang tua dalam mendidik anaknya pun berbeda dengan pendidikan anak pada zaman era 80 -an. Peradaban manusia di zaman ini sudah memasuki dunia informasi, misalnya televisi yang selalu hadir dalam kehidupan anak atau remaja dengan mempertontonkan budaya barat sehingga sebagian besar mempengaruhi perilaku anak.

Berdasarkan survey yang telah dilakukan di "Jakarta, Bandung, Semarang, Surabaya, Medan dan Makasar" tentang kegiatan sehari-hari yang dilakukan oleh anak-anak. Dalam survey tersebut, dilaksanakan pada anak berumur 7-14 tahun dan ibu dari anak berusia 0-14 tahun dengan strata sosial yang berbeda-beda. Hasil dari survey tersebut, menunjukkan bahwa anak sudah terbiasa dengan televisi sejak bayi sebanyak $25 \%$. Setelah menginjak lebih dari satu tahun, anak-anak dalam melakukan kegiatannya tidak terlepas dari televisi sebanyak 92\%. Dan setelah menginjak pada usia masuk TK sampai ke SMP, anak-anak sudah menjadi penggemar televisi. Kehadiran televisi dalam hidup anak-anak dengan adegan iklan yang menarik dan pembunuhan telah membawa pesona anak dalam dunia khayal. ${ }^{6}$

Selain itu, di zaman era informasi saat ini, bukan saja perilaku menyimpang yang dilakukan oleh remaja, tetapi dilakukan juga yang masih usia anak-anak yang masih Sekolah Dasar. Akhir-akhir ini kita dikejutkan dengan berbagai macam komplotan geng siswa yang masih sekolah yang mencontohi geng dalam televisi seperti pukul memukul, main kroyok dan macam lain lagi bentuknya. ${ }^{7}$ Fenomena yang terjadi, menggambarkan potret pendidikan Indonesia saat ini sangat mengkhwatirkan. Padahal, masa remaja adalah masa kenangan dan harapan yang perlu diukir dengan "tinta emas" dan seharusnya perbuatan yang dilakukan banyak mengandung manfaat bagi dirinya maupun bagi masyarakat, bangsa dan Negara.

Berkembangnya arus globalisasi saat ini, telah membawa perubahan yang besar bagi kehidupan manusia, tetapi disisi lain membawa perubahan yang sangat tidak berarti. Kecanggihan teknologi komunikasi yang ditandai dengan internet yang sebenarnya banyak manfaatnya untuk mengakses informasi dengan cepatnya dan dengan murahnya, tetapi internet hanya dijadikan sebagai

\footnotetext{
${ }^{6}$ Sigit Muryono, Empati: Penalaran Moral Dan Pola Asub: Telaah Bimbingan Konseling (Yogyakarta: Cawan Mas, 2009), hlm. 6-7.

${ }^{7}$ Munjin, "Internalisasi Nilai-Nilai Budi Pekerti Pada Anak," Dakwah Dan Komunikasi 2, no. 2 (2008), hlm. 219.
} 
topeng bagi remaja untuk melihat adegan-adegan "syur" yang tidak perlu dijadikan bahan pertontonan.

Menurut Yasraf Amir Piliang, ${ }^{8}$ masuknya dunia informasi kepada anak telah memberikan budaya yang baru bagi anak. Padahal sejak dulu tontonan orang dewasa tidak boleh ditonton oleh anak., tetapi sekarang ini dunia sudah terbalik, saat ini tontonan anak hampir sama dengan tontonan orang dewasa. Dampak dari era globalisasi tersebut, bukan saja berdampak pada masyarakat yang tinggal di perkotaan, tetapi merembas juga pada daerah pedesaan, seperti halnya yang terjadi pada Desa Merabuan Dusun Teluk Sebasung Kecamatan Tangaran Kabupaten Sambas.

Menurut Pakar sosiolog agama, Elizabeth K. Nottingham, menjelaskan bahwa masyarakat yang tinggal di daerah pedesaan dikategorikan sebagai masyarakat yang menerima arus perubahan lambat karena masih kental dengan tradisi nenek moyang. ${ }^{9}$ Seperti halnya pada Desa Merabuan, pada zaman sejarahnya berawal dari masyarakat yang membuka hutan di utara Sambas untuk dijadikan suatu kampung dan lahan bercocok tanam atau bertani yang cukup luas. Nama Desa Merabuan berawal dari sebuah pohon atau kayu yang namanya Merabuan, sehingga pada saat itu Desa Merabuan dikenal sebagai Kampung Merabuan. ${ }^{10}$

Desa Merabuan adalah salah satu desa yang ada di Kabupaten Sambas yang merupakan Provinsi Kalimantan Barat yang memiliki luas wilayah $6.395,70 \mathrm{~km}^{2}$ atau $639.570 \mathrm{ha}$, yang terletak pada bagian pantai barat paling utara dari wilayah provinsi Kalimantan Barat. Panjang pantai $\pm 128,5 \mathrm{~km}$ dan panjang perbatasan negara $\pm 97 \mathrm{~km} .{ }^{11}$

Merabuan adalah sebuah Desa yang jauh dari keramaian dan dikategorikan desa yang masih tertinggal dari desa lain dengan keterbatasan infrastruktur yang masih belum memadai, tetapi perbuatan perilaku yang menyimpang tidak dapat juga dihindarkan, bahkan hampir tak kalah juga dengan kenakalan remaja yang terjadi di kota-kota besar.

\footnotetext{
8 Yasraf Amir Piliang, Dunia Yang Telah Dilïpat: Tamasya Melampani Batas-Batas Kebudayaan (Bandung: Matahari, 2011), hlm. 10.

${ }^{9}$ Elizabeth K. Nottingham, Agama Dan Masyarakat: Suatu Pengantar Sosiologi Agama, terj. Abdul Muis Nahorang (Jakarta: CV.Rajawali, 1996), hlm. 49-66.

${ }^{10}$ Hadari Nawawi, Metodologi Penelitian Bidang Sosial (Yogyakarta: Gajahmada Universiti Press, 1990).

${ }^{11}$ https://id.wikipedia.org/wiki/Kabupaten_Sambas, di akses tanggal 2 April 2016.
} 
Berdasarkan penjajakan awal yang telah dilakukan, ${ }^{12}$ dampak dari era informasi saat ini yang terjadi di Desa Merabuan Dusun Teluk Sebasung dengan kategori penduduk sekitar 34 buah rumah. Remaja yang putus sekolah dan masih sekolah mencapai 25 orang dengan kategori umur 13-18 tahun. Alasan putus sekolah, dikarenakan orang tua tidak mendukung anaknya untuk sekolah. Di antara pengaruh media televisi yang terjadi pada Dusun Teluk Sebasung adalah dari "grup band" yang bernama ST 12 dan "Raja". Keseluruhan remaja yang tinggal di Teluk Sebasung tersebut, terpengaruh dari budaya "grup band' yakni memakai anting telinga dan gaya rambut seperti tokoh artis yang ada pada "grup band" tersebut.

Budaya yang ditampilkan oleh anak remaja di Dusun Teluk Sebasung adalah termasuk kategori budaya Barat yang bertentangan dengan nilai-nilai masyarakat setempat maupun nilai-nilai budaya yang ada. Jika, diilihat dari letak geografisnya Dusun Teluk Sebasung Desa Merabuan Kecamatan Tanggaran sangat jauh dari pusat-pusat perkotaan. Sebuah desa kecil dengan mayoritas penduduk muslim, ekonomi masyarakatnya rata-rata ke bawah karena bekerja sebagai petani musiman yakni bertani. Sementara, jika dilihat dari segi ekonomi, agama, maka tidak pantas remajanya berperilaku kebarat-baratan, bahkan meninggalkan budaya ketimuran. Kalau sudah demikian, maka orang desa bisa ter"kota"kan gaya hidupnya meskipun mereka belum pernah ke kota. Orang bisa menjadi barat atau terbaratkan sekalipun mereka belum pernah ke barat. Kenyataan itulah yang terjadi di masyarakat Dusun Teluk Sebasung Desa Merabuan Kecamatan Tanggaran yang sudah mulai terkontaminasi oleh budaya asing dengan anting telinga yang dilakukan dikalangan remaja laki-laki yang sewajarnya, perbuatan tersebut yang berhak memakai anting adalah remaja putri atau wanita.

Masalah kebolehan wanita melubangi daun telinganya untuk menggantungkan anting-anting, diperselisihkan oleh ulama. Dalam AshShahihain disebutkan, ketika Nabi SAW menekankan para wanita untuk bersedekah, ada di antara mereka yang menyedekahkan anting-antingnya. Hadits ini cukuplah sebagai dalil tentang bolehnya wanita memakai antinganting, sebagaimana Allah SWT berfirman dalam Q.S. An-Nisa [4] : 119 sebagai berikut:

\footnotetext{
${ }^{12}$ Observasi pada tahun 2010 sejak mengangkat judul skripsi ini.
} 


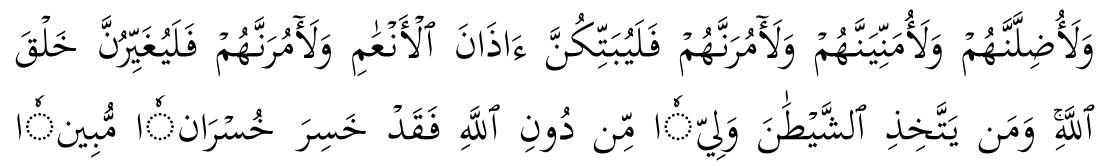

Artinya:

"Dan Aku benar-benar akan menyesatkan mereka, dan akan membangkitkan angan-angan kosong pada mereka dan menyuruh mereka (memotong telinga-telinga binatang ternak), lalu mereka benarbenar memotongnya, dan akan Aku suruh mereka (mengubah ciptaan Allah), lalu benar-benar mereka meubahnya. barangsiapa yang menjadikan syaitan menjadi pelindung selain Allah, Maka Sesungguhnya ia menderita kerugian yang nyata." 13

Berdasarkan paparan diatas, peneliti ingin melakukan pengkajian lebih mendalam tentang pendidikan yang diberikan oleh orang tua kepada anaknya yang berusia remaja yang sudah terpengaruh oleh budaya asing dan telah menjadi internalisasi budaya bagi diri remaja di Desa Merabuan yang tinggal di Dusun Teluk Sebasung tersebut.

\section{Metode}

Penelitian ini menggunakan penelitian lapangan (field research), yaitu untuk mendeskripsikan dan menganalisis fenomena yang terjadi sesuai dengan apa yang diteliti. ${ }^{14}$ Jenis penelitian yang digunakan dalam penelitian ini adalah metode deskriptif sesuai dengan fakta dilapangan yang akan diteliti. ${ }^{15}$ Menurut Arikunto $^{16}$ penelitian deskriptif merupakan penelitian untuk mengumpulkan informasi berdasarkan keadaan gejala apa adanya dilapangan. Gejala yang dimaksud dalam penelitian ini adalah gejala yang sebenarnya terjadi pada remaja yang tingga di Desa Merabuan Dusun Teluk Sebasung tersebut.

Subjek penelitian ini adalah keluarga yang berada di Desa Merabuan Dusun Teluk Sebasung. Penelitian ini hanya mengambil beberapa keluarga yang mempunyai anak remaja baik yang masih sekolah maupun tidak lagi

\footnotetext{
${ }^{13}$ Departemen agama, Al-Qur'an dan Terjemahannya (Jakarta: Depag RI, 1995), h. 997.

${ }^{14}$ Nana Syaodih Sukmadinata, Metode Penelitian Pendidikan, (Bandung: PT Remaja Rosdakarya Offset, 2009), h. 60.

${ }^{15}$ Nawawi, Metodologi Penelitian Bidang Sosia, hlm. 631.

${ }^{16}$ Suharsimi Arikunto, Prosedur Penelitian Suatu Pendekatan Praktek (Yogyakarta: PT Rineka Cipta, 2002), hlm. 234.
} 
sekolah, yakni sekitar lima keluarga. Sedangkan yang menjadi objek penelitian ini adalah orang tua dan Remaja.

Teknik pengumpulan data dalam penelitian ini menggunakan wawancara, ${ }^{17}$ observasi, ${ }^{18}$ dan dokumentasi. ${ }^{19}$ Sementara Teknik analisis data yang digunakan dalam penelitian ini menggunakan teori Miles dan Huberman yaitu reduksi data, penyajian data dan penarikan kesimpulan. Sedangkan teknik pemeriksaan keabsahan data dalam penelitian ini adalah perpanjangan keikutsertaan, Triangulasi, ${ }^{20}$ dan Members Check. ${ }^{21}$

\section{Pembahasan}

Penelitian ini mengkaji pendidikan remaja dalam keluarga di Dusun Teluk Sebasung Desa Merabuan Kecamatan Tangaran Kabupaten Sambas dalam perspektif pendidikan agama Islam. Orang tua dalam memberikan pendidikan kepada anaknya yang usia remaja adalah anak yang terpengaruh dari budaya barat yakni anting telinga atau tindik telinga. Orang tua dalam memberikan pendidikan kepada anaknya adalah dengan berbagai macam upaya yang dilakukan. Upaya adalah "usaha atau syarat untuk menyampaikan suatu maksud". ${ }^{22}$ Sedangkan dalam penelitian ini yang dimaksud dengan upaya adalah usaha orang tua untuk memberi kesadaran kepada anaknya, bahwa perbuatan

\footnotetext{
${ }^{17}$ Wawancara diartikan sebagai percakapan dengan maksud tertentu yang dilakukan oleh dua pihak, yakni pewawancara (interviewer) yang mengajukan pertanyaan dan yang di wawancarai (interviewer) yang memberikan jawaban atas pertanyaan itu., untuk lebih jelasnya baca Lexy J. Moleong, Metodologi Penelitian Kualitatif (Bandung: PT Remaja Rosda Karya, 1991).

${ }^{18}$ Diartikan sebagai pengamatan yang dilakukan kemudian peneliti melakukan pencatatan berdasarkan gejala yang tampak pada saat melakukan penelitian. Untuk lebih jelasnya, baca Nawawi, Metodologi Penelitian Bidang Sosial, hlm. 100.

${ }^{19}$ Dokumentasi berasal dari kata dokumen yang artinya barang tertulis, misalnya data yang diperoleh melalui buku-buku, arsip, catatan harian, dan dokumen lainnya. Untuk lebih jelasnya baca Arikunto, Prosedur Penelitian Suatu Pendekatan Praktek, hlm. 135.

${ }^{20}$ Teknik pemeriksaan keabsahan data yang memanfaatkan sesuatu yang lain di luar data itu untuk keperluan pengecekan atau sebagai pembanding terhadap data itu. Untuk lebih jelasnya lihat Moleong, Metodologi Penelitian Kualitatif, hlm. 178.

${ }^{21}$ Members check adalah untuk melakukan pengecekan kembali terhadap data yang telah terkumpul tentang upaya orangtua mengatasi remaja laki-laki memakai anting ditinjau dari Pendidikan Agama Islam dan data yang berkaitan dengan faktor penghambatnya. 22 Pius A. Partanto and M. Dahlan Al Barry, Kamus Ilmiah Populer (Surabaya: ARKOLA, 1994), hlm. 579.
} 
dengan memakai anting telinga adalah tidak boleh dalam ajaran agama Islam. Oleh karena itu, sebagai Orang tua dalam memberikan pendidikan kepada anaknya yang sudah terinternalisasi dari budaya barat adalah berupa nasihat. Nasihat yang baik dari pengaruh budaya barat tersebut menurut orang tua remaja Dusun Teluk Sebasung adalah suatu keharusan., karena anak adalah amanah dari Allah. Selain itu, orang tua juga berkewajiban untuk menciptakan keluarganya yang aman, tentram dan damai atau dalam istilahnya menciptakan keluarga yang sakinah, mawaddah dan warahmah.

Pendidikan yang diberikan bukan saja sampai masa anak-anak, tetapi sampai menginjak remaja atau dewasa. Oleh karena itu, salah satu syarat yang tidak boleh ditunda-tunda untuk menciptakan suasana tersebut dan memberi pendidikan yang baik kepada anak, selayaknya orang tua seharusnya mempunyai pendidikan dan tahu tentang agama. Karena, pendidikan yang pertama dan utama yang diberikan kepada anak adalah melalui sosialisi orang tua. ${ }^{23}$ Melalui sosialisasi dalam keluarga, karena keluarga adalah "satu persekutuan hidup yang dijalin oleh kasih sayang antara pasangan dua jenis manusia yang dikukuhkan dengan pernikahan, yang bermaksud untuk saling menyempurnakan diri". ${ }^{24}$ Keluarga merupakan lingkungan pertama yang dikenal oleh anak setelah anak lahir. Keluarga adalah tempat pendidikan yang dilakukan oleh orang tua kepada anaknya. ${ }^{25}$ Orang tua secara kodratnya adalah pendidik bagi anak-anaknya, sehingga secara fitrahnya rasa kasih sayang telah muncul dalam hati orang tua.

Pendidikan agama Islam yang diberikan kepada anak dapat mempengaruhi karakter anak sesuai dengan tujuan pendidikan agama Islam, seperti yang diutarakan oleh Azyumardi Azra. ${ }^{26}$ Ia menjelaskan bahwa tujuan pendidikan Islam untuk menciptakan manusia yang beriman dan bertakwa kepada-Nya agar dapat mencapai kebahagian di dunia dan di akhirat. Sementara Zakiah

\footnotetext{
${ }^{23}$ Syaiful Bahri Djamarah, Pola Komunikasi Orang Tua Dan Anak Dalam Keluarga; Sebuah Perspektif Pendidikan Islam (Jakarta: PT. Rineka Cipta, 2004), hlm. 85.

${ }^{24}$ Moh. Shochib, Pola Asuh Orang Tua; Untuk. Membantu Anak Mengembangkan Disiplin Diri (. Jakarta: PT. Rineka Cipta, 2000), hlm. 17.

${ }^{25}$ Hasby Wahy, "Keluaraga Sebagai Basis Pendidikan Pertama Dan Utama," Jurnal Ilmiah Didaktika XII, no. 2 (2012), hlm. 245.

26 Azyumardi Azra, Pendidikan Islam; Tradisi Dan Modernisasi Menuju Milenium Baru (Jakarta: Logos, 1999), hlm .8.
} 
Drajat, ${ }^{27}$ menjelaskan dengan memahami ajaran Islam dan mengamalkannya maka dapat dijadikan landasan sebagai pedoman hidup. Oleh karena itu, bimbingan yang diberikan kepada anak sesuai dengan ajaran Islam. ${ }^{28}$ Pendidikan yang tidak pernah henti-hentinya yang diberikan kepada anak, agar hasil dari pendidikan tersebut, bukan saja sebagai investasi di dunia tetapi dapat juga sebagai investasi diakhirat bagi orang tua.

Dampak dari gejala yang timbul oleh era informasi yang ditandai dengan banyaknya remaja yang melakukan tindak kriminal, bahkan juga meniru gaya hidup budaya asing seperti tindik telinga (anting). Hal ini menurut Usef Fathuddin bahwa seharusnya masa remaja bukan melakukan tindakan yang amoral yang dapat merugikan diri sendiri, tetapi masa remaja adalah masa dimana remaja sadar akan kematangan yang ada pada dirinya. ${ }^{29}$ Oleh karena itu, menjadi orang tua bukanlah semudah membalikkan telapak tangan dalam pribahasa yang arti dengan mudahnya, tetapi menjadi orang tua yang dapat memberikan keteladan kepada anak, sehingga dari keteladan tersebut dapat dicontoh oleh anak-anak yang hidup di zaman era informasi saat ini.

Adapun bentuk-bentuk upaya yang dilakukan oleh Orang tua dalam mengatasi anaknya memakai anting tidak terlepas dari nasihat yang diberikan. Bentuk dari nasihat tersebut tergantung dari situasi anaknya yang berusia remaja. Jika remaja tersebut mendengar, maka nasihat yang diberikan hanya sampai disitu saja. Seandainya, nasihat tidak didengarkan oleh anaknya, maka akan dilakukan nasihat secara kasar. Bahkan jika nasihat itu juga tidak berhasil, maka orang tua berani mengancam anaknya dengan kata-kata jika kamu masih memakai anting tersebut maka kamu tidak boleh tinggal di rumah ini. Dengan adanya ancaman tersebut, sehingga anak di Dusun Teluk Sebasung tidak lagi memakai anting atau tindik telinga. ${ }^{30}$

\footnotetext{
27 Zakiah Drajat, Problematika Remaja Di Indonesia (Jakarta: Bulan Bintang, 1999), hlm. 86.

28 Samsul Nizar, Filsafat Pendidikan Islam; Pendekatan Historis, Teoritis Dan Praktis (Jakarta: Ciputat Press, 2002), hlm. 32.

${ }^{29}$ Usef Fathudin, Risalah Remaja Dan Agama (Jakarta: Depag RI, 1990), hlm. 10.

${ }^{30}$ Wawancara yang hampir sama jawabannya yang dilakukan kepada Bapak Marani, Sumarji, Abun, Gunawan dan Ibu Mardiah, pada tahun 2010 di tempat kediaman bapak/ibu tersebut. adapun isi wawancara menggunakan bahasa daerah melayu Sambas sehingga kata aslinya seperti di bawah ini: "Bentuk kegiatan adalah melarang, melarang udah ditegur udah diberi nasehat, tutur kata, tapi masih menantang udah dipukul dia pun akhirnya lari dari rumah jadi kondisinya masih seperti itu, tapi
} 
Di antara nasihat yang telah diberikan, tidak terlepas juga berbagai metode yang digunakan. Metode yang dianggap mampu untuk menyadarkan remaja, menurut orang tua yang telah dilakukan wawancarai sebanyak lima orang adalah dengan menggunakan metode ketergantungan menurut situasi dan kondisi anak. metode ketergantungan yang dimaksud adalah metode keteladanan untuk menumbuhkan kesadaran, metode pembiasaan untuk selalu membiasakan perbuatan yang bernilai positif., metode hukuman yang digunakan bagi anak yang tidak mendengarkan., metode hadiah yang digunakan, jika anak tidak lagi melakukan perbuatan tersebut atau sudah mulai menyadari., metode nasihat yang dilakukan secara lansung melalui tatap muka kepada anak dan metode Tanya jawab untuk mendengarkan ucapan anak, mengapa melakukan hal tersebut. ${ }^{31}$

Dalam hal ini, peneliti memetakan contoh upaya yang dilakukan orang tua dalam memberikan pendidikan kepada anaknya yang sudah menginjak remaja yang dikarenakan sudah terinternalisasi budaya barat yakni anting telinga atau tindik telinga yang dianggap metode ketergantungan yang sesuai dalam perspektif pendidikan agama Islam di Dusun Teluk Sebasung Desa Merabuan. Metode ketergantungan yang dimaksud adalah:

1. Metode pembiasaan

Kebiasaan adalah perbuatan yang dilakukan secara berulang-ulang oleh orang tua dalam mendidik anaknya. Kebiasaan yang dilakukan selalu setiap saat., misalnya salah satu kebiasaan yang dilakukan oleh orang tua dalam mendidik anaknya adalah selalu mengajak anak untuk pergi ke Mesjid secara bersama-sama, agar nantinya, tanpa secara sadar anak sudah terbiasa ketika mendengar adzan anak sudah siap-siap untuk pergi ke Mesjid tanpa ajakan dari orang tua lagi.

\section{Metode Keteladanan}

Orang tua yang baik adalah orang tua yang selalu mengajarkan anak dengan nilai-nilai Islam. Oleh karena itu, untuk menjadi orang tua yang bisa digugu dan ditiru adalah selalu setiap saat memberikan keteladanan yang baik bagi anak. Teladan yang bernilai positif selalu diajarkan kepada anak, maka nantinya anak akan mengikuti dari teladan orang tuanya juga.

sekarang tidak lagi ia memakai anting-anting atau subang, sedangkan aku iyekan udah nyata pun kau maseh makai iye kamu jangan pulang kerumah. Pun kamu masih mautinggal dirumah, kamu harus membuang anting-anting atau subang yang tak seharusnya kamu pakai".

${ }^{31}$ Observasi yang dilakukan pada tahun 2010. 
3. Metode hukuman dan hadiah

Orang tua dalam memberikan hukuman adalah apabila anak tidak menuruti perintah atau keinginan orang tua sehingga nantinya akan berakibat tidak akan mendapatkan hadiah dari orang tua. Hukuman yang diberikan kepada remaja di Dusun Teluk Sebasung yang menggunakan anting telinga adalah di usir dari rumah. Mendengar hukuman dari orang tuanya, sehingga mau tidak mau anak mengikuti perintah orang tuanya agar mendapat hadiah yakni tidak jadi di usir dari rumah. Jika dilihat dari hukuman orang tua yang diberikan kepada anaknya yang sudah menginjak remaja dapat dikategorikan sebagai hukuman dengan secara tegas tanpa ada toleransi sedikit pun.

4. Metode nasihat

Nasihat yang diberikan oleh orang tua kepada anaknya yang sudah menginjak remaja adalah secara bertahap-tahap. Tahap pertama di nasihati secara halus., jika anaknya tidak peduli dari nasihat orang tuanya, maka orang tuanya menasehatinya dengan secara kasar.

5. Metode Tanya Jawab

Orang tua yang melihat perilaku anaknya yang tidak sesuai dengan nilainilai agama membuat hati orang tua bertanya-tanya. Oleh karena itu, orang tua lansung bertanya kepada anaknya, mengapa perilaku mencontoh dari budaya barat kenapa dilakukan. Padahal perilaku tersebut adalah tidak sesuai dengan agama yang kita yakini yakni agama Islam. Islam melarang anak lelaki memakai anting, karena perbuatan tersebut adalah perilaku setan yang seharusnya di pakai oleh anak perempuan.

Di antara metode yang digunakan oleh orang tua, tidak terlepas dari faktor pendukung dari keberhasilan dari metode tersebut. Faktor pendukung yang dimaksud dalam penelitian ini adalah orang tua dalam memberi kesadaran kepada anaknya, agar tidak memakai anting atau tindik telinga dan gaya rambut yang "tren masa kini" diantaranya adanya peran serta tokoh masyarakat, dukungan orang tua dalam memberikan nasehat dan dorongan kepada remaja agar tidak lagi memakai anting, dan selaku orang tua selalu ikut serta program dari kepala Desa Merabuan. ${ }^{32}$ Adapun faktor penghambat yang menjadi kendala dalam memberikan pendidikan agama Islam kepada remaja agar tidak terlibat dari perbuatan negatif yang merugikan dirinya sendiri disebabkan oleh kesibukan orang tua sehingga kurang membimbing remaja laki-laki, lemahnya pengaruh Pendidikan Agama Islam terhadap remaja laki-laki, ketidakpedulian

${ }^{32}$ Wawancara yang dilakukan kepada Bapak Sumarji, Ibu Mardiah, Ibu Nursila dan Bapak Abun pada tahun 2010. 
orang tua dan adanya pengaruh negatif dari media elektronik, misalnya televisi dan internat. ${ }^{33}$

\section{Simpulan}

Berdasarkan uraian yang telah peneliti kemukakan sebelumnya, peneliti menyimpulkan beberapa hal yang berkaitan dengan pendidikan remaja dalam keluarga di Desa Merabuan Dusun Teluk Sebasung Kecamatan Tangaran dengan analisis perspektif Pendidikan Agama Islam, di antaranya:

Pertama, berkaitan dengan bentuk kegiatan yang dilakukan orang tua dalam mengatasi remaja laki-laki memakai anting ditinjau dari Pendidikan Agama Islam di Desa Merabuan Dusun Teluk Sebasung Kecamatan Tangaran, di antaranya adalah nasihat. Bentuk dari nasihat yang diberikan adalah terdiri dari beberapa tahapan tergantung anak mendengar atau tidaknya. Selain itu juga, metode yang digunakan dalam memberikan pendidikan anak dalam lingkungan keluarga adalah dengan metode pembiasaan, keteladanan, metode hukuman dan hadiah, metode nasihat, metode tanya jawab

Kedua, faktor pendukung yang dialami oleh orang tua dalam mengatasi remaja memakai anting ditinjau dari pendidikan Agama Islam di Desa Merabuan Dusun Teluk Sebasung Kecamatan Tangaran diantaranya adanya dukungan orang tua dalam, kesadaran masyarakat, peran serta tokoh masyarakat. Sementara faktor penghambatnya, di antaranya kesibukan orang tua, lemahnya pengaruh pendidikan Agama Islam, ketidakpedulian orang tua dan adanya pengaruh negatif media elektronik.

\footnotetext{
33 Wawancara yang dilakukan kepada Bapak Sumarji dan Ibu Mardiah pada tahun
} 2010. 


\section{Daftar Pustaka}

Agama, Departemen. Al-Qur'an dan Terjemahannya. Jakarta: Depag RI, 1995.

Ahmadi. Sosiologi Pendidikan. Jakarta: Rineka Cipta, 2004.

Arikunto, Suharsimi. Prosedur Penelitian Suatu Pendekatan Praktek. Yogyakarta: PT Rineka Cipta, 2002.

Azra, Azyumardi. Pendidikan Islam; Tradisi Dan Modernisasi Menuju Milenium Baru. Jakarta: Logos, 1999.

Bahri, Syaiful. Psikologi Pendidikan. Jakarta: Akademika Presido, 1999.

Chen, Bruce. Sosiologi Sebagai Pengantar. Jakarta: Rineka Cipta, 1992.

Djamarah, Syaiful Bahri. Pola Komunikasi Orang Tua Dan Anak Dalam Keluarga; Sebuah Perspektif Pendidiken Islam. Jakarta: PT. Rineka Cipta, 2004.

Drajat, Zakiah. Problematika Remaja Di Indonesia. Jakarta: Bulan Bintang, 1999. Fathudin, Usef. Risalah Remaja Dan Agama. Jakarta: Depag RI, 1990.

Faturochman. "Peranan Keluarga, Sekolah Dan Masyarakat Dalam Pembentukan Kepribadian Remaja.” Laporan Hasil Penelitian Fakultas Psikologi, Universitas Gajah Mada, t.th.

Lestari, Widayati. "Peran Orang Tua Dalam Pendidikan Seks Pada Remaja." Laporan Hasil Penelitian, Universitas Muhammadiyah Surakarta, 2015.

Moleong, Lexy J. Metodologi Penelitian Kualitatif. Bandung: PT Remaja Rosda Karya, 1991.

Munjin. "Internalisasi Nilai-Nilai Budi Pekerti Pada Anak." Dakwah Dan Komunikasi 2, no. 2 (2008).

Muryono, Sigit. Empati: Penalaran Moral Dan Pola Asub: Telaah Bimbingan Konseling. Yogyakarta: Cawan Mas, 2009.

Nawawi, Hadari. Metodologi Penelitian Bidang Sosial. Yogyakarta: Gajahmada Universiti Press, 1990.

Nizar, Samsul. Filsafat Pendidikan Islam; Pendekatan Historis, Teoritis Dan Praktis. Jakarta: Ciputat Press, 2002.

Nottingham, Elizabeth K. Agama Dan Masyarakat: Suatu Pengantar Sosiologi Agama. Terj. Abdul Muis Nahorang. Jakarta: CV.Rajawali, 1996.

Partanto, Pius A., and M. Dahlan Al Barry. Kamus Ilmiah Populer. Surabaya: ARKOLA, 1994.

Piliang, Yasraf Amir. Dunia Yang Telah Dilïpat: Tamasya Melampaui Batas-Batas Kebudayaan. Bandung: Matahari, 2011.

Shochib, Moh. Pola Asuh Orang Tua; Untuk Membantu Anak Mengembangkan Disiplin Diri. . Jakarta: PT. Rineka Cipta, 2000. 
Soemanto, Wasty. Pola Asub Orang Tua Dalam Membantu Anak. Mengembangkan Disiplin Diri. Jakarta: Rineka Cipta, 1998.

Wahy, Hasby. "Keluaraga Sebagai Basis Pendidikan Pertama Dan Utama." Jurnal Ilmiah Didaktika XII, no. 2 (2012). 